GLOBAL RESEARCH ETHICS

\title{
Professional responsibilities of biomedical scientists in public discourse
}

\section{U Schüklenk}

J Med Ethics 2004;30:53-60. doi: 10.1136/jme.2003.002980

This article describes how a small but vocal group of biomedical scientists propagates the views that either HIV is not the cause of AIDS, or that it does not exist at all. When these views were rejected by mainstream science, this group took its views and arguments into the public domain, actively campaigning via newspapers, radio, and television to make its views known to the lay public. I describe some of the harmful consequences of the group's activities, and ask two distinct ethical questions: what moral obligations do scientists who hold such minority views have with regard to a scientifically untrained lay audience, and what moral obligations do mainstream newspapers and government politicians have when it comes to such views. The latter question will be asked because the "dissidents" succeeded for a number of years in convincing the South African government of the soundness of their views. The consequences of their stance affected millions of HIV infected South Africans severely.

Correspondence to:

Dr U Schüklenk, Head,

Division of Bioethics,

Faculty of Health Sciences,

University of the

Witwatersrand,

Johannesburg, Wits 2050,

South Africa;

udo@udo-schuklenk.org

Accepted 13 June 2003
E ver since the retrovirus HIV was declared to be the cause of AIDS, a small but vocal group of scientists has argued in professional journals and publicly either that HIV is not the cause of AIDS, or that there is no evidence that HIV exists at all.

Scientists should be aware of the social harm that can result from the premature proclamation of claims that are weakly founded. Scientists must be particularly careful when their science deals with questions of human import. They have entered the political arena.

The self declared "HIV dissidents" blame other putative causes for AIDS, including the health consequences of highly active sex lives involving drug taking and multiple partners in developed countries, and/or poverty in developing countries. $^{2}$ They allege that essential AIDS drugs are one of the real causes of AIDS. A corollary of this position has been the view that AIDS is not infectious at all.

Jürgen Habermas's insights into our "erkenntnisleitendes Interesse" encourage me to come clear at this stage and declare that I was one of those vocal HIV dissident academics. Some years ago I changed sides in this dispute and accepted that mainstream views of HIV and AIDS are correct. Since I changed my views on this matter, I also happen to have changed my employer. I moved from developed world Australia with its rather small number of people with AIDS, to developing world South Africa, reportedly the country with the largest number of AIDS cases worldwide. Prevalence rates in the country among persons aged 15-49 years old are around $15 \% .^{3}$ Perhaps surprisingly for the uninitiated observer, the South African government's publicly expressed views on HIV and AIDS, and its policies with regard to the provision of essential AIDS drugs have for a number of years mimicked, in important ways, the views of HIV dissidents. There is some evidence that the government stance on HIV/AIDS moved closer to mainstream views in 2002, but the question of whether this will translate into realistic HIV/ AIDS policies remains unanswered at the time of writing. The publicly expressed views of the South African President, Mr Thabo Mbeki, and his health minister, medical doctor Manto Tshabalala Msimang, are very strongly influenced by the views of HIV dissidents.

In this article, I describe in some detail the inner workings of the HIV dissident group, and its impact on high risk groups in developed countries, as well as its impact on South African government policies. My attention will then turn to two interesting ethical questions that arise in this context. The first question is to do with the issue of what responsibilities biomedical professionals have towards a scientifically unqualified public. In the case under consideration, HIV dissidents took their initially scientific dispute out of the arena of biomedical journals, with their standard processes of anonymous peer review, into the public domain, campaigning on TV and in gay magazines, daily newspapers, and similar publications. Indeed, their internet based offerings $^{45}$ persuaded South African President Thabo Mbeki to take their views seriously. The consequences for the provision of essential AIDS drugs to those HIV infected among the country's impoverished masses were grave.

The question I should like to pose is this: if you are a biomedical scientist who fails to convince your peers of your views on a particular matter of legitimate scientific inquiry, is it acceptable that you take your minority views "to the streets" in order to drum up public and media support for your stance? I will also examine whether one can legitimately blame the proponent of such a minority position for decisions made by members of the public who decide to act on such a minority view. 
The second ethical question is to do with the ethical responsibilities of leading politicians and government officials towards their sovereign, the citizens of their country. I shall argue that the South African government has, over many years, neglected its moral obligations towards HIV infected individuals and people with AIDS, while pursuing AIDS policies strongly influenced by dissident views.

\section{THE DISSIDENTS}

Much of the dissidents' claim to fame and public recognition is based on original work and analysis undertaken by a German American biochemist, Peter Duesberg, based at the University of California. In 1987, he published a major review article in the journal Cancer Research. ${ }^{6}$ This article evaluated the available evidence concerning the pathogenicity of retroviruses. There soon followed another major review article in the US Proceedings of the National Academy of Sciences. ${ }^{7}$ Duesberg, a highly decorated and elected member of the academy, effectively concluded that there is no evidence that HIV causes AIDS. A few years later he complemented his stance on HIV with his own hypothesis as to what the causes of AIDS are. ${ }^{28}$ His views were quickly taken on board by some gay activists in the USA, including the late Michael Callen, a founding member of the People with AIDS Coalition in New York City, and John Lauritsen, a writer with the now defunct weekly New York Native, as well as many others. I started writing articles in a Berlin based monthly AIDS magazine called vor-sicht (perhaps best translated as be careful or have foresight). All these writings appeared quite early on in the epidemic. No life extending AIDS medication existed at the time. People died in ever growing numbers of one or another of the opportunistic infections now captured in the definition of AIDS. It certainly seemed prudent to me at the time to give support to critics of a hypothesis, the pursuit of which had done little to bring those in need closer to life extending or life saving AIDS drugs. Very early on, however, there were already obvious flaws in Duesberg's publicly expressed opinion on HIV and AIDS. He stated categorically that HIV is not the cause of AIDS, ${ }^{9}$ while all he could have reasonably claimed on the basis of his analysis was that it had not been proven that HIV causes AIDS. Then there existed epistemological problems, such as the never resolved dispute between Duesberg and mainstream scientists over what constitutes proof of causation in the biomedical sciences. Still, Duesberg is no quack, and such was his personality that he actively sought the limelight, courting journalists as much as they courted him. A sharp and witty character, he quickly succeeded in gathering support. A group was established under the banner of "Rethinking AIDS". Indeed, one of the dissidents, physiologist Robert Root-Bernstein published a book under this title. ${ }^{10}$ This group consists of signatories to a petition demanding a thorough re-appraisal of the HIV/AIDS hypothesis.

It is worth having a closer look at the members of this group. Among its more influential members are a number of former Duesberg colleagues at the University of California at Berkeley, including Harvey Bialy, formerly editor at large of Nature/Biotechnology, and Kary Mullis, an iconoclastic Nobel laureate who was awarded the prize for his discovery of the polymerase chain reaction method. Other members are Berkeley law professor Phil Johnson, best known for his creationist writings, assorted gay activists, and biomedical scientists, many of whom have their own pet theory as to what causes AIDS. The group regularly points to a substantial number of scientists supportive of its agenda to re-evaluate the HIV/AIDS hypothesis. Some of those members still listed are people who have been dead for a number of years. While it is correct that these people supported the objective of a scientific re-evaluation of the HIV/AIDS link when they were alive, it is clearly difficult to ascertain what these people would have made of the scientific developments and the accumulation of evidence for HIV as the crucial causative agent in AIDS, which has occurred in the years after their deaths.

My own conversion to the mainstream view took place roughly when dissident predictions about AIDS deaths resulting from what they believed were highly poisonous drug cocktails-that is, triple therapy, did not occur and when it became clear that actually the opposite was true; these drugs were at least life extending. I saw people with AIDS, following years of decline, turn the corner after they began using these drugs. Dissidents would dispute this by various means, including claiming scientific fraud. Having seen with my own eyes the decline of close friends stop and revert, I was no longer, for all practical intent and purposes, an HIV dissident. This is not to deny that there remain important open questions, including some very fundamental ones such as: by what exact direct or indirect mechanisms HIV causes AIDS, and why the epidemiology of AIDS is so dramatically different on the African continent than it is in the USA, Europe, and most South East Asian countries.

A second group of dissidents is led by Eleni PapadopulosEleopulos, a medical physicist based at Royal Perth Hospital in Australia. This group claims that HIV has never been fully isolated and seems to imply that it has not been proven that HIV does exist as a distinct entity at all. ${ }^{11}$ Duesberg certainly agrees that HIV does exist, but he believes it is a harmless passenger virus as opposed to the causative agent in AIDS.

My contributions as a bioethicist were mostly of a critical nature. As it happened, some of the group's predictions turned out to be true. For instance, during the years when the developed world was gripped by dire predictions about gigantic HIV/AIDS waves, tips of the iceberg metaphors and so forth, public health promotion campaigns designed to threaten those countries' citizens with death if they refused to take proper precautions, were launched. This was a classic example of the health/belief model of health promotion campaigns in action. The dissidents claimed there was nothing remotely resembling such an epidemic anywhere in the developed world. They predicted furthermore, that AIDS would remain restricted to the same high risk groups it was affecting at the time, namely men who have sex with men and intravenous (IV) drug users. I subscribed to those predictions and argued in several publications that it is ethically problematic to scare a whole population indiscriminately into changing its sexual behaviour based on questionable empirical evidence and predictions. ${ }^{12}$ Most bioethicists' writings on AIDS in the late 1980s and early 1990s were based on those types of predictions, see-for example, papers by Overall and Zion and Häyry and Häyry. ${ }^{13}{ }^{14}$ I criticised the uncritical adoption of those predictions. While history has proven my analysis to be correct, it is worth noting that without my own ultimately flawed views on the HIV/AIDS connection, it would not have occurred to me to take the stance I took at the time. Alert peer reviewers of professional bioethics journals prodded me into establishing my conclusions without relying on the truth of the dissident position. Thanks to them, I do not find myself in a situation where I would have to withdraw anything I actually published in professional journals on AIDS-another outcome of the so often maligned process of peer review. Arguably, many of the publications that celebrated the "ethical issues" of a nonexistent heterosexual AIDS epidemic in developed countries did a disservice to the profession and to the public. 


\section{HIV dissidents' high public profile}

Dissident scientists and their lay support base did not limit their activities to legitimately questioning the mainstream consensus in scientific journals. The most obvious way of testing scientific hypotheses and theories is to present counterevidence and counterarguments. The dissidents, however, decided also to take their views to a broader audience. Duesberg's views featured prominently in feature length TV programmes in most developed English speaking countries, including the USA, the UK, Canada, and Australia. The Sunday Times in London ran several month-long campaigns designed to make a mockery of the mainstream consensus on HIV and AIDS. ${ }^{15} \mathrm{I}$ am not entirely innocent with regard to content provided in Berlin's magazine vor-sicht, at the time a widely read monthly, non-peer reviewed AIDS magazine, targeting primarily gay men in major metropolitan areas of Germany. Magazines such as Continuum in the UK targeted HIV infected individuals specifically, with issue after issue questioning the link between HIV and AIDS. Its pages are littered with advertisements for alternative concoctions such as homoeopathy, complementary medicine, and other more or less absurd approaches to AIDS disease management. Scientists among the dissidents used this non-peer reviewed magazine to thrash out arguments about content and personality in public. When eventually two of the magazine's founders died of AIDS related illnesses, the dissident denial machine went into overdrive, speculating about the men's former drug taking habits, the numbers of sex partners they had had, and pretty much any "cause" other than HIV.

Part of the dissidents' appeal was their claim that the "establishment" was censoring their views. Evidently, nothing could have been further from the truth. The pros and cons of dissident arguments were evaluated with their active participation in mainstream journals, including Science, Cancer Research, Proceedings of the National Academy of Sciences, AIDS Forschung, Genetica, and many others. In other words, while it may be true that exchanges between mainstream scientists and the dissidents have been acrimonious and at times emotional, there is little evidence that this impacted negatively on mainstream scientists acting as professional peer reviewers for leading medical journals; had it been otherwise, the dissidents would never have seen their work in print. The group's initial reason for existence, a public appeal for a scientific re-evaluation of the HIV/AIDS hypothesis, was published in Science. ${ }^{16}$ Scientists among the HIV dissidents used their academic credentials and academic affiliations to generate interest, sympathy, and allegiances in lay audiences. They were not professionally troubled about recruiting lay people-who were clearly unable to evaluate the scientific validity or otherwise of their views-to their cause. I shall return to this theme in a moment.

\section{Consequences of HIV dissidents' public campaigning in the developed world}

Inevitably, millions of people subjected to dissident views in TV programmes and their favourite broadsheets, will respond in a variety of different ways. To my knowledge, no scientific surveys were undertaken to analyse what impact such views had on people belonging to high risk groups in developed countries. The anecdotal evidence I gathered from discussions on public and private emailing lists, subscribed to by people with HIV/AIDS, is that indeed (some) HIV positive people stopped practising safer sex, refused to inform their sexual partners about their HIV status, and also changed their treatment regimes. I vividly recall arguing on such a private mailing list with an HIV infected gay man about the issue of safer sex. He argued that there was little reason to use condoms because AIDS clearly was not infectious (as HIV dissident Professor Duesberg had shown), and that therefore he would not allow the "establishment" to take the fun out of his sex life. Members of the dissident group actively encouraged his stance at the time. On an infected individual's website, several years ago, I was thanked for providing arguments critical of Zidovudine monotherapy (the early firstline therapeutic response to AIDS targeting the causative agent directly). That individual strongly believed he owed his life to my publications. Based on arguments I provided, he decided not to follow his doctor's advice to begin taking Zidovudine. It turned out that my scepticism about a "hit HIV early, hit it hard" with the Zidovudine monotherapy treatment strategy was confirmed years later by more sophisticated clinical research. Again, coincidentally, and luckily for me, my dissident convictions led to the publication of arguments and conclusions that history confirmed as correct. My own anecdotal evidence is supported by similar reports gathered in an article by the San Francisco based AIDS Foundation. ${ }^{17}$ What is important, however, is that such publications, as well as the high profile activities of dissident scientists such as Duesberg, influenced a lay public's decisions with regard to treatment regimes and HIV protective behaviours.

I think that while one can legitimately question whether scientists should engage in such public campaigning and posturing at a time when their argument is considered lost by their peers, there is no good reason to deny such professionals the opportunity to have their say publicly if they so wish, provided at least one condition is met: those infected individuals who make choices such as those described must be aware of the fact that the views expressed by dissidents are those of a very small minority of scientists. They must fully understand that the odds of these views being correct are minuscule at best. This does not contradict my earlier claim that lay people are unable to understand or evaluate the validity or otherwise of dissident views. My point is that at a more basic level they must understand how exceedingly small the number of professionals is who hold dissident views. In that sense, their decision to adopt the dissident stance is very much an autonomous choice. ${ }^{18}$ It is a choice that is authentically their own. It is a considered choice that results in such individuals rejecting the advice of mainstream health promotional programmes. It is a considered choice to reject mainstream physicians' advice. Arguably, therefore, the responsibility for their decisions, and actions-and the consequences of those decisions and actions-is largely their own. ${ }^{19}$

\section{The South African context}

A number of important empirical facts change the moral evaluation of dissident activities when looked at from a developing country, and particularly when that country is in Southern Africa. Unlike in the developed world, the vast majority of people in developing countries are able neither to evaluate the validity of dissident claims, nor to understand how small the number of professionals who support such views actually is. I mentioned some salient facts about the scope of the epidemic in South Africa in my introductory remarks. Let me add a few pieces of additional information: in the year 2000, between 4.7 and 6 million of 40 million South Africans were reported to be HIV infected. ${ }^{20}$ A 1999 study of HIV infections among women seeking assistance in the country's antenatal clinics registered prevalence rates between $5.2 \%$ and $32.2 \%$, depending on the province in question.

Some African governments, such as that of Uganda, have responded with mass education campaigns and attempts to increase access for as many of their infected citizens as possible to essential AIDS drugs. This is not the case with the 
South African government. The main reason is that the country's president, Mbeki, has lent his support to HIV dissident views. He has campaigned both publicly and behind the scenes to justify his government's policy of not providing essential AIDS drugs to the majority of South Africa's infected citizens. While Mbeki has prevaricated on this issue, a quote from a subsequent speech he gave strongly suggests that HIV dissident views are at the core of his government's response to the AIDS crisis in the country:

Thus it happens that others who consider themselves to be our leaders take to the streets carrying their placards, to demand that because we [black people] are germ carriers, and human beings of a lower order that cannot subject its [sic] passion to reason, we must perforce adopt strange opinions [such as mainstream views on HIV and AIDS], to save the depraved and diseased people from perishing from self inflicted disease. ... Convinced that we are but natural born, promiscuous carriers of germs, unique in the world, they proclaim that our continent is doomed to an inevitable mortal end because of our unconquerable devotion to the sin of lust. ${ }^{21}$

The director of the country's HIV/AIDS Law Project, Mark Heywood, commented that these views "appear to describe those who believe AIDS is a virologically caused, mostly sexually transmitted disease that can be medically contained, as stigmatising and demeaning black people". ${ }^{21}$ The ANC's national leadership regurgitated these views in a lengthy document, taking a strongly HIV dissident stance:

For their part, the Africans believe this story, as told by their friends. They too shout the message that-yes, indeed, we are as you say we are! Yes we are sex-crazy! Yes we are diseased! Yes, we spread the deadly HIV virus through our uncontrolled heterosexual sex! In this regard, yes we are different from the US and Western Europe! Yes, we, the men, abuse women and the girl-child with gay abandon! Yes, among us rape is endemic because of our culture! Yes, we do believe that sleeping with young virgins will cure us of Aids! Yes, as a result of all this, we are threatened with destruction by the HIV/Aids epidemic! Yes, what we need, and cannot afford because we are poor, are condoms and antiretroviral drugs! Help! ... Scare mongering ... is condemning millions of our own people to ill health, disability, and death because of a refusal to recognise the critical importance of the diseases of poverty and other illnesses that afflict our people, including STDs. This is done to sustain a massive politicalcommercial campaign to promote antiretroviral drugs. ... Strange as it may seem, given what our friends tell us about the Virus everyday, nobody has seen it, including our friends. Nobody knows what it looks like. ${ }^{22}$

South African academic Mandisa Mbali argues, quite convincingly, that while modern AIDS activism is concerned about access to treatment, Mbeki as a postcolonial African leader is fighting a different political battle, trying to assert an "African Renaissance" in response to racism, apartheid, and colonialism. ${ }^{22}$ He also went on the record in Time magazine, stating: "You cannot attribute immune deficiency exclusively to a virus". ${ }^{23}$ During parliamentary question time, he asked: "Does HIV cause AIDS? Can a virus cause a syndrome? How?"24 These views are mirrored in statements made by his health minister, which slam mainstream scientists and pharmaceutical companies for advocating antiretroviral drugs "because they have a vested interest in doing so" $^{\prime 25}$ There have been some, albeit inconclusive, indications that the author of the ANC document was Mbeki himself, because the embedded electronic signature of the document traces it back to: "Author: Thabo Mbeki", and "Company: Office of the President", as an investigative report in a local newspaper revealed. ${ }^{26}$

What these quotes suggest, is that Western dissident views have seemingly persuaded the powerful president of the developing country with the largest reported number of AIDS cases worldwide, to support their take on HIV and AIDS. The former president of the country's Medical Research Council called Mbeki's activities and views on this matter a "national scandal". ${ }^{27}$ Mbeki established a presidential advisory panel stacked with dissidents and accompanied by some mainstream scientists, at great financial cost to the country. The panel's deliberations led nowhere. Its establishment betrayed a gross misunderstanding of the process of scientific inquiry. Mbeki hoped to facilitate some sort of consensus or compromise between dissidents and mainstream scientists, as if the question of scientific truth was a matter of democratic consensus finding.

What is of greater interest for our purposes, however, is how the dissidents used their elevated status (that is, of someone appointed to the presidential advisory panel) to influence public discussions in South Africa. Mbeki, who during 2002 apparently had another conversion and seemed more prepared to accept mainstream views on AIDS, reportedly instructed his health ministry to write to the dissidents and request that they refrain from signing their public statements as members of his advisory panel..$^{28}$ This is one of many instances of dissidents using their affiliations (in this case, their membership of Mbeki's expert panel) to boost their credibility. A few characteristic quotes that dominated the print media for months follow. Professor Sam Mhlongo, head of family medicine at the Medical University of South Africa is a member of the dissident group. Interestingly, at the time of writing he had not published a single peer reviewed original paper based on empirical research on AIDS.*

His main line of attack, unsurprisingly, is that Nevirapene, a drug proven to work, and recommended by both the World Health Organization and UNAIDS because it reduces the likelihood of the mother to child transmission of HIV from an infected pregnant woman, "is a notoriously very toxic drug". He insists that HIV has "never in the history of the AIDS era been isolated". ${ }^{29}$ Dissident presidential panellist David Rasnick, from the USA, declared in interviews with local newspapers that "Africans are suffering and dying from the same things they have been suffering and dying from for generations before AIDS. They are not suffering and dying from something new called AIDS". He is also reportedly convinced that "AIDS was neither contagious, sexually transmitted nor caused by HIV and that anti-AIDS drugs accelerated death or made people sick with AIDS". Utilising the sensitivities of South Africans with regard to the issue of apartheid, he reportedly claims that "South Africans were now being ruled by the 'tyranny' of orthodox science in the same way as [they were ruled by] the country's white minority leaders under apartheid". ${ }^{30}$ Rasnick stressed his membership of Mbeki's expert panel in his letters to editors of local newspapers.

\section{Ethical issues}

Central to my discussion of ethical concerns is a statement made by Art Amman, head of Global Strategies for HIV Prevention. He said: "After reviewing the volumes of communication having to do with Duesberg disciples,

Medline search undertaken 14 Nov 2002.* 
personally listening in court for two days to these individuals, and surveying the damage they are invoking, I am trying to reach some conclusions and think about a rational approach to limiting their future damage and influence" ${ }^{27}$ There are various ethical issues that should be raised with regard to the dissidents' activities in South Africa, as well as the country's president's obvious failing to engage in a process of due diligence, before he decided on the country's response to what is probably the most serious health disaster in South Africa's history. It seems useful to begin by depicting how democratic developed societies responded to dissident views: dissidents were allowed to have their say in professional journals, and, as we have seen, in the mass media. The latter is a questionable way for a professional to pursue academic grievances, but clearly democratic liberal values at the heart of these societies permitted the dissidents' publicity seeking activities to go ahead. What were the ethical reasons for this? Undoubtedly, they had much to do with the attitudes so eloquently stated in John Stuart Mill's treatise On Liberty: "If all mankind minus one were of one opinion, mankind would not be more justified in silencing that one person, than he, if he had the power would be justified in silencing mankind". ${ }^{31}$ What were Mill's arguments in support of this view?

\section{We have now recognised the necessity to the mental wellbeing of mankind of freedom of opinion, and freedom of the expression of opinion on four distinct grounds (...): first, if any opinion is compelled to silence, that opinion may, for all we can certainly know, be true. To deny this is to assume our own infallibility. Secondly, though the silenced opinion may be an error, it may and very commonly does, contain a portion of truth (...). Thirdly, even if the perceived opinion be not only true, but the whole truth; unless it is suffered to be, and actually is, vigorously and earnestly contested, it will, by most of those who receive it, be held in the manner of a prejudice, with little comprehension or feeling of its rational grounds. (...) Fourthly, the meaning of the doctrine itself will be in danger of being lost, or enfeebled, and deprived of its vital effect on the character and conduct: the dogma becoming a mere formal profession, inefficacious for good, but cumbering the ground, and preventing the growth of any real and heartfelt conviction, from reason or personal experience (Mill J S, ${ }^{31}$ pp 111-12).}

While these are powerful reasons to legally permit scientists to espouse minority views, there are good ethical reasons why they ought to voluntarily refrain from campaigning publicly for their views. These reasons have to do with their moral obligations to the public, as professionals. Before I get to those reasons, however, let us have a closer look at Mill's arguments. He is effectively stating that we should allow freedom of expression because otherwise we would run the risk of suppressing a view that could have been the correct one, or that could have contained a kernel of truth. In addition, those holding the mainstream view could quite possibly hold it without critical reflection on it, and without knowing why they are holding it. In fact, the mainstream paradigm may merely become a formality repeated by us without good reason. While all these arguments, to my mind, tip the scales in favour of freedom of academic expression in professional journals, according to the standard rules of academic debate they are too weak to serve as a justification for the type of campaigning described in this article. After all, whether or not the dissident view is erroneous (Mill's first point) will never be settled in the letters' pages of daily newspapers in South Africa, or on talkback radio shows in the US or on TV programmes in Canada or Australia. Even looked at from a dissident perspective, it seems obvious that the objective of "winning the day" cannot be achieved by winning over the lay public. As to Mill's last point, I am happy to concede that I trust mainstream science's findings sufficiently to accept them as prima facie correct. It is unreasonable to expect anything other of me. The odds are highly stacked against minority views of the sort that concentration camps did not exist in Nazi Germany (as proposed frequently by holocaust deniers), that high concentrations of vitamin $\mathrm{C}$ kill cancer, or indeed that a traditional stage healing of a quadriplegic by a reverend belonging to a charismatic church ever took place.

\section{PROFESSIONALISM AND THE PUBLIC GOOD}

Most professions are characterised, among other things, by the fact that their members pledge, usually publicly during graduation ceremonies, to abide by codes of ethics. Invariably these codes of ethics contain pledges promising to serve the interests of clients or patients, and the public good. ${ }^{32} 33$ Indeed even most modern codes of professional ethics reflect the religious derivation of the term professionalism, meaning to profess publicly to serve the public good. I think that these professional ethical obligations toward the public may well serve as a factor limiting professionals' claims to freedom of (public) speech. In the case under consideration, the argument in support of this view could be sketched like this: scientists among the HIV dissidents know that among their peers the number of people sharing their views is minuscule at best. While this is not proof of the wrongness of their views, it provides the dissenters with strong professional ethical reasons to refrain from running high profile public campaigns designed to sway a lay public, after their failure to convince the professional public. While there are examples in the history of minority views whereby scientific matters turn out to be correct, dissidents have good historical reasons to acknowledge that this is not usually the case. If dissident views had indeed been systematically censored by a mainstream HIV science conspiracy, arguably the dissidents would have been entitled to alert the public to this fact and also to aim to have the professional process of anonymous, unbiased peer review re-established. It is important to note, however, that this has not been the case. Dissidents have had plenty of opportunities to argue their case in professional journals. After a process of due diligence, health authorities in most countries have begun health promotion campaigns designed to inform their citizens about the risks of unsafe sex, and the benefits of HIV testing, given the availability of life extending (if not life saving) treatments. The public interest is not served by dissidents' attempts to convince the lay public that their views are correct and that AIDS is not contagious, HIV is not the cause of AIDS, or indeed that HIV does not exist at all. There is some anecdotal evidence that members of high risk groups in developed countries have taken dissidents' views sufficiently seriously to change their AIDS related risk assessments, including stopping the use of condoms to prevent an infection. While the responsibility for such choices should be placed mostly on the shoulders of those individuals who made them, clearly HIV dissidents are not entirely innocent either. Without their publicity seeking behaviours, it is unlikely that many lay people would have taken notice.

Turning to South Africa, there is more than anecdotal evidence to suggest that the dissident activities had negative health consequences. The following excerpt was published in a local broadsheet.

Nkululeko Nxesi, the national director of the National Association of People Living with HIV and AIDS, said his organisation was experiencing rejection of the message that HIV caused AIDS "on a daily basis". "At the end of 


\begin{abstract}
the day, I think people will want to hear the news that HIV does not cause AIDS," he said. "It is affecting what we're doing. It's not even two steps back, it's like ten steps back. And it was such a struggle to encourage people to engage in safer sex in the first place." AIDS Consortium director Morna Cornell said that, while she did not have firsthand experience of rejection of the AIDS message, she had heard anecdotal reports of confusion. Recently a friend had told her how she had been involved in an educational discussion on HIV in KwaZulu-Natal, where people had asked why they needed to use condoms if HIV did not cause AIDS. ${ }^{34}$
\end{abstract}

Winstone Zulu, an AIDS patient, recounts the undesirable consequences of the president's support for the dissident stance on AIDS. Zulu initially took antiretrovirals to maintain his health. After stopping the use of antiretroviral medications, his health deteriorated and he eventually went back on life saving essential AIDS drugs. Zulu explains how Mbeki's tacit support for dissident views convinced him that they were right. "With Mbeki coming in, I believed it was the link I needed to believe this," he explains. "When I saw that Mbeki was doubting, I thought this was right."."35

A 2002 representative HIV prevalence study, undertaken by the country's Human Sciences Research Council, reveals that condom use and behavioural changes toward safer sex are lower among people who either believe HIV is not the cause of AIDS or who admit to being uncertain about the virus's role in the causation of AIDS, when compared to people who believe HIV is the cause of AIDS. The authors of this study conclude: "correct, unequivocal knowledge that HIV causes AIDS ... is strongly associated with self reported behaviour change over the past few years as a response to the risk of HIV infection, condom use in the last sexual experience, and discussion of HIV prevention with a partner". ${ }^{3}$ About one in five respondents reported doubts about the question of whether HIV causes AIDS.

My argument thus far suggests that professionals in the biomedical sciences who hold the minority view have particular professional ethical obligations to refrain from campaigning publicly among lay audiences, for support for their professional views. These reasons have to do with the idea that professionals ought to serve the public good. The public good is not served by scientists whose views have been rejected by their peers, and who are trying to "win" the scientifically lost case in the lay public's domain. It also seems professionally irresponsible to impose the "truth" of one's views on a lay audience while knowing full well that this audience is not equipped to evaluate the scientific merits or otherwise of one's arguments. At the same time, of course, nothing should prevent professionals holding minority views in their field of expertise from making their case in professional journals, provided standard procedures of anonymous peer review have been followed. This is also in the public's best interest, because it constitutes a sound procedure for testing and (re)-evaluating scientific hypotheses and theories.

What counterarguments could be advanced against the position developed so far? Some might be worried that my proposal would lead us down a slippery slope toward general legally imposed restrictions of free speech placed upon professionals. There is little that can be said with regard to this argument, other than that there is no reason to assume that a society would move easily from a voluntary self restriction to outlawing such freedom of speech.

Even consequentialists, possibly persuaded by my argument that the dissidents caused unacceptable harm to the public good, might, however, be worried about the question of whether it is possible to put my proposal into action at an operational level. After all, while most scientists tend not to look for the media limelight immediately, many professional journals alert the mass media to the latest findings in their field by way of distributing their table of contents via email to subscribing journalists. Inevitably, health journalists will contact the authors for media comments. How should scientists respond to such calls? Perhaps one way of answering this question is to acknowledge that minority views can be held on a range of issues. Some such views may affect only small numbers of people, or if acted upon, may result in harmful but reversible consequences. Under such circumstances, while the scientists still ought to restrain themselves in their interactions with the media, the consequences of their information sharing would lead only to limited negative consequences. In cases where potentially large numbers of people might make problematic choices influenced by "dissident" scientists, however, one would hope to see such professionals acknowledge and stress in their interactions with journalists, that the vast majority of their colleagues do not share their views and that there is a fair chance that they might have got this one wrong. Certainly, dissident scientists should not actively go about spreading their views in the mass media. This undoubtedly would have made a difference in the case I have described. The public good would have been better served if the protagonists had acted along the lines suggested. The troublesome issue of how scientists should respond to the mass media's exploitation of their work is, of course, not limited just to the issue of minority view scientists. Jon Beckwith demonstrates this nicely both in his discussion of geneticists' work on a putative "criminal chromosome" and also in his discussion of misconceptions (amongst the general public) generated by the mass media's reports on published research (Beckwith $\mathrm{J}^{1}$ ch 8 ).

\section{POLITICIANS AND THE PUBLIC GOOD}

The consequences of dissident scientists' public campaigns were particularly grave in South Africa. The country's president, after stumbling across dissident views on one of his travails on the internet, seems to have made their views more or less his own. The consequences were disastrous by any interpretation of what the public good would have required the government of that country-which has the largest reported number of HIV infections and AIDS cases in the world-to do. The South African government did everything possible to delay the provision of essential AIDS drugs to the impoverished masses, relying on public sector health care delivery. Initially, the government insisted that essential AIDS drugs were too expensive. When prices came down the true dissident colours of the government became more obvious. It insisted, among other things, that AIDS drugs were poisoning South African Blacks, ${ }^{36}$ that the drugs were not proven to be effective, ${ }^{25}$ and that it is doubtful that viruses cause disease syndromes. These views were mirrored by at least one provincial African National Congress (ANC) health minister, who reportedly fired a hospital director in Mpumalanga province for providing a hospital room to a non-governmental organisation supporting rape survivors with counselling, clean clothes, and postexposure medication. The politician justified her decision with this statement: "The health and lives of our poor black people were placed under serious threat by this organisation which claimed to have their interests at heart".37

In court cases brought about by treatment access activist groups, the government went so far as to misrepresent a scientist's research findings in order to prevent a courtfinding requiring it to provide medication designed to 
drastically reduce the mother to child transmission of HIV. The author of the findings went out of his way to inform the court in an affidavit that the government's summary of his work and the conclusions drawn from it did not reflect his views. Professor Robin Wood's second affidavit can be found at www.tac.org.za. ${ }^{38}$

The argument supporting my contention that the South African government failed its moral obligations toward the citizens of the country is easy to make, and is similar to the case brought against the HIV dissidents. While it is true that politicians are not professionals and therefore have no professional ethical obligations toward the public, they have other ethical obligations, stemming from their role as elected representatives of the people. Democratically elected governments are morally obliged to serve the needs and interests of their sovereign, that is, the citizens of the country. ${ }^{39}$ The South African government clearly failed on this count.

\section{THE ROLE OF THE MEDIA}

South African news media behaved responsibly in this affair, by and large. The activities of the presidential advisory panel none the less dominated the newspapers for some time. With the exception of the letters pages of the Johannesburg daily, The Star, however, the dissidents were provided with comparatively little space to propagate their views. Indeed, Mbeki and his government were subjected to a continuous barrage of scathing criticism. The Star provided a great deal of space for a public spat between a local academic and a US based dissident. The dissident was challenged to have himself injected with HIV if he was so convinced HIV was not causing the immunodeficiency. The publicity seeking HIV dissidents succeeded yet again in getting into the world media limelight, because the challenge was reported widely, even in newspapers in places as far away as Singapore and Australia. Arguably, if the country's president had not lent his support to the dissident cause by way of inviting many dissidents onto his advisory panel on AIDS, the US based scientist involved in the challenge would probably not have received any publicity. The letters editor of that same newspaper influenced the public debate by publishing over months, letters written by dissidents. This misled the reading public into believing that there was a major debate taking place, while what really happened was that the local dissidents mobilised the few supporters they had in various countries. The question is whether daily newspapers with large scientifically illiterate audiences, have a responsibility to their readership not to publish scientifically internationally discredited views. It seems clear that the letters editor of the paper in question has failed basic rules of journalism ethics in this regard.

\section{THE ROLE OF THE MEDICAL PROFESSION}

Various responses to the challenges that the HIV dissidents and their high placed supporters in South Africa's national and provincial governments posed, emanated from the organised medical profession. The South African Medical Association intervened at the height of presidential denialism with a consensus statement, reading in $\operatorname{part}^{40}$ :

\section{Whilst SAMA welcomes any debate on health it is obliged to point out that the view that HIV may not cause AIDS has been thoroughly discredited by several recent scientific studies. This view is dangerous and its propagation may lead to cases of AIDS that may have otherwise been prevented.}

The country's two leading health sciences faculties of the universities of the Witwatersrand and Cape Town, issued public statements criticising the government for its flawed response to the AIDS crisis and its prevarications on the issue of what causes AIDS. The chairman of the South African Medical Association harshly criticised the government in a speech and press release, and went so far as to accuse it of committing genocide by acts of omission-that is, by failing to provide poor South Africans with access to essential AIDS drugs. Bioethicists in the country acted responsibly. Some of the leading bioethicists actively criticised the government's stance, even organising a high profile petition and press release demanding the re-instatement of the hospital director who was fired in Mpumalanga province for offering facilities to the rape survivor group. Some doctors in public sector hospitals worked hard to find ways to subvert government policies and regulations, and to provide as many needy patients as possible with access to essential AIDS drugs. The Medical Research Council published a report debunking $\mathrm{Mr}$ Mbeki's public questioning of AIDS statistics, declaring that AIDS was the number one cause of death in the country. Its president subsequently resigned, only to describe to a journalist from The Economist how he and other scientists were subjected to government threats and bullying. The magazine reported: "The scientist accuses the minister of threatening that he will be fired and 'forgotten by history' for opposing the government policy and statements on AIDS". The scientist comments that the minister "is trying to overrule science with politics. It is very frightening". ${ }^{41}$ Jonathan Glover in his book Humanity-A Moral History of the 20th Century provides an excellent analysis of the psychological underpinnings of such government activities. ${ }^{42}$ Malegapuru Makgoba, the past President of the South African Medical Research Council, who is himself an accomplished immunologist, published his first high profile commentary on the dissidents in Science. ${ }^{43}$

It is fair to say that the response to the dissident saga of the organised medical professions in South Africa, unlike its response to challenges such as the death of Steve Biko, some 25 years ago, ${ }^{44}$ has been vigorous. In that sense, many public sector health care professionals' responses to a typical dual loyalties based conflict were settled not in favour of the government's demands, but in favour of their patients. They took their professional codes of ethics and their public pledges to put their patients' interests first seriously.

\section{CONCLUSION}

I have argued in this article that scientists holding minority views on particular issues affecting the general public should voluntarily refrain from campaigning for their views among the lay public. The case described in some detail in this article demonstrates convincingly the great harm done by HIV dissident scientists to the wellbeing of people with HIV and AIDS all over South Africa. News media with large scientifically illiterate audiences have particular professional responsibilities toward their readers not to propagate such minority views. Governments should be particularly diligent in their evaluation of such minority scientists' views and should be as a matter of principle very cautious in adopting such minority views when developing public policy.

A possible way forward would seem to be the development of ethical guidelines, similar to the World Medical Association's Declaration of Helsinki, by organisations such as the American Society for the Advancement of Science, the British Association for the Advancement of Science and others. Quite possibly this could be a task for international umbrella organisations such as the Council for International Organisations of Medical Science (CIOMS) to take on. These guidelines could develop frameworks for scientists' interactions with the wider (lay) public. If scientists digress, 
journalists, for instance, as well as politicians would have good reasons to be concerned about their activities and have good prima facie reasons to reject the advice offered by such individuals. Science organisations could consider censuring publicly such publicity seeking scientists.

\section{ACKNOWLEDGEMENTS}

This article is dedicated to the memory of Carlton Hogan, who died on 18 November 2003. I am grateful to my research assistant Vernon Naidoo for tracing relevant dissident quotes in the news media, as well as Mandisa Mbali, Lynne Altenroxel, Thofi S Bishop, Edwin Cameron, Romi Fuller, Sam Gorovitz, Trefor Jenkins, Bonnie Steinbock and Tim Trengove-Jones for helpful assistance with, and/ or feedback on, earlier drafts of this article. Richard Ashcroft and an anonymous reviewer critically and diligently reviewed this paper for the Journal of Medical Ethics. Both are thanked for triggering changes of (and hopefully improvements to) this paper.

\section{REFERENCES}

1 Beckwith J. Making genes - making waves. Boston: Harvard University Press, 2002.

2 Duesberg PH. AIDS: acquired by drug consumption and other non-contagious risk factors. Pharmacol Ther 1992;55:201-77.

3 Shisana O, Simbayi L. South African national HIV prevalence, behavioural risks and mass media-household survey 2002. Cape Town: Human Sciences Research Council, 2002

4 http://www.duesberg.com (accessed 27 Nov 2002).

5 http://www.virusmyth.com (accessed 27 Nov 2002).

6 Duesberg PH. Retroviruses as carcinogens and pathogens: expectations and reality. Cancer Res 1987:47:1199-220.

7 Duesberg PH. HIV and AIDS: correlation but not causation. Proceedings of the National Academy of Sciences 1989;86:755-64.

8 Duesberg PH, Rasnick D. The AIDS dilemma: drug diseases blamed on a passenger virus. Genetica 1998;104:85-132.

9 Duesberg PH. HIV is not the cause of AIDS. Science 1988;241:514, 517.

10 Root-Bernstein R. Rethinking AIDS: the tragic cost of premature consensus. New York: Free Press, 1993.

11 Papadopulos-Eleopulos E, Turner VF, Papadimitrious JM. Is a positive Western blot proof of HIV infection? Bio/Technology 1993;11:696-707.

12 Schüklenk U, Mertz D, Richters J. The bioethics tabloids: how professional ethicists have fallen for the myth of tertiary transmitted heterosexual AIDS. Health Care Anal 1995;3:27-36.

13 Overall C, Zion WP. Perspectives on AIDS. Ethical and social issues. Oxford University Press: Ontario, 1987.

14 Häyry H, Häyry M. AIDS now. Bioethics 1991;1:339-56.

15 Page B. The Murdoch archipelago. London: Simon \& Schuster, 2003.

16 Baumann E, Bethell T, Bialy H, et al. AIDS proposal: group for the scientific reappraisal of the HIV/AIDS hypothesis. Science 1995;267:1080.

17 SF AIDS Foundation. HIV causes AIDS. http://www.sfaf.org/aboutsfaf/ outreach/index.html?june00/hiv_causes_aids.html (accessed 15 Nov 2002).

18 Feinberg J. The moral limits of the criminal law: harm to self. New York: Oxford University Press, 1986.

19 Schüklenk U. Access to experimental drugs in terminal illness: ethical issues. New York: Haworth, 1998.
20 Rensburg DV, Friedman I, Ngwena C, et al. Strengthening local government and civic response to the HIV/AIDS epidemic in South Africa. Bloemfontein: Centre for Health Systems Research and Development, University of the Free State, 2002.

21 Forrest D, Streek B. Mbeki bumbles into another AIDS debate. Mail \& Guardian 2001 Oct 28:4.

22 Mbali M. Mbeki's denialism and the ghosts of apartheid and colonialism for post-apartheid policy making. http://www.nu.ac.za/ccs/files/mbeki.pdf (accessed 2 Dec 2003).

23 Karon T. You cannot attribute immune deficiency exclusively to a virus. Time 2001 Sept 11. http://www.time.com/time/nation/article/ 0,8599,54515,00.html (accessed 13 Nov 2003).

24 Harvey M. How can a virus cause a syndrome, asks Mbeki. http:// www.aegis.com/news/woza/2000/IC000906.html (accessed 25 Nov 2003).

25 Staff writer. Minister slams AIDS drug propaganda. Mail \& Guardian 2002 Nov 8:2.

26 Barrell H. Would the real AIDS dissident please reveal himself. Mail \& Guardian 2002 Apr 19:2

27 Sulcas A. Mbeki's AIDS call alarms scientists. Sunday Independent 2000 Mar 18. http://iol.co.za/index.php?set_id = 1\&click_ld = 13\&art_ id = ct20000318190723156M120177 (accessed 9 Dec 2003).

28 Underhill G. Mbeki's AIDS torch shines on in cyberspace. Cape Argus 2002 Aug 15. (http://iol.c.za/index.php? set_id = 1\&click_id = 13\&art $\mathrm{id}=\mathrm{ct} 20020815215207868$ A323213 (accessed 25 Nov 2003).

29 Staff writer. Medunsa AIDS dissident "advises" health minister. Mail \& Guardian 2002 May 9:2.

30 Reuters. Africans aren't dying of AIDS, dissident says. http://www.iol.co.za/ index.php? set_id = 1 \&click_id = 13\&art_id = qw986571664810B243 (accessed 14 Nov 2002).

31 Mill JS. On liberty. London: JM Dent, 1960:79.

32 Koehn D. The ground of professional ethics. London: Routledge, 1994.

33 Chadwick RF, ed. 1994. Ethics and the professions. Aldershot: Ashgate, 1994.

34 Altenroxel L. AIDS debate may undermine youth sex habits. The Mercury 2000 Sept 24. http://iol.co.za./index.php?set_id = 1\&click_id = 13\&art_ id = ct20000924195506660H100945 (accessed 9 Dec 2003).

35 Altenroxel L. Wish you were right says Mbeki's AIDS man. The Star $2002 \mathrm{Jul}$ 19. http://iol.co.za. /index.php? set id = 1 \&click id = 13\&art id = ct20020719111700345H13285 (accessed 9 Dec 2003).

36 Farham B. Time for Manto to resign. Mail \& Guardian 2002 Jul 19: 24.

37 Altenroxel L. Insubordinate doctor fights to keep working. The Star 2002 Feb 28. http://iol.co.za./index.php? set id = 1 \& click id = 13\&art id $=$ ct20020228211611332T215494 (accessed 9 Dec 2003).

38 http://www.tac.org.za/Documents/MTCTCourtCase/affidavit/ robinwoodreplyaffidavit doc (accessed 15 Nov 2002).

39 Singer P. One world: the ethics of globalization. New Haven: Yale University Press, 2002.

40 South African Medical Association. HIV causes AIDS. SAMJ 2000;90:461

41 Anon. Leave them be: South African scientists deplore their government's meddling [editorial]. The Economist 2002 Apr 6: 77

42 Glover J. Humanity-a moral history of the 20th century. London: Jonathan Cape, 1999.

43 Makgoba MW. HIV/AIDS: The Peril of Pseudoscience. Science 2003;288: 1171 .

44 McLean GR, Jenkins T. The Steve Biko affair: a case study in medical ethics. Developing World Bioeth 2003;3:77-95. 